\title{
Mavi Bisiklet Filminin Çocuk Temsili Bağlamında İncelenmesi
}

\author{
The Analysis of Mavi Bisiklet (Blue Bicycle, 2016) in the Context of The \\ Representation of Child
}

\section{Ömür Yıldırım}

Yüksek Lisans Öğrencisi, Ordu Üniversitesi Sosyal Bilimler Enstitüsü Sinema ve Televizyon Anabilim Dalı, 16omur16@gmail.com

\section{$\ddot{O z z}$}

Sinemayı içinde bulunduğu toplumdan ayrı düşünmek olanaksızdır. Sinema bulunduğu toplumda, o toplumun ekonomik, siyasi, kültürel öğelerinin etkisiyle var olmaktadır. Türk sineması 2000 yılından sonra Türkiye'de oluşan değişimler sonucunda yeni bir arayış içine girmiştir. Türk sineması bağımsız filmlerin ülkeye getirdiği ödüller ile dünyaya kendini tanıtmaya çalışmaktadır. Türk yönetmenler tarafından sıkça kullanılan çocuk kahramanlar gözünden anlatılan film örnekleriyle, Mavi Bisiklet filminin çocuk imgesi bağlamında incelenmesi yapılmıştır. Mavi Bisiklet filminde kullanılan sinema dili, çocuk oyuncuların kendi hayatlarından kesitler şeklinde sunulan oyunculuk deneyimleri ve sade anlatı yapısı filmin seyirciye başarılı bir şekilde aktarılmasını sağlamıştır. Tüm bunların sonucunda Mavi Bisiklet filminin başarısının nedeni ve yönetmenin çocuk imgesini sinema diline nasıl yansıttığı incelenmiş ve Ümit Köreken'in filminin analizi yapılmıştır.

Anahtar Kelimeler: Yeni Türk Sineması, Mavi Bisiklet, Çocuk, Sinema, Toplum, Kültür, Sinemada Çocuk

\begin{abstract}
It is impossible to consider cinema separately from the very society in which cinema is located. Cinema comes into existence in a society via the influence of economic, political and cultural elements comprised by that society. Turkish cinema has embarked on a new quest as a result of the changes in Turkey after 2000. The analysis of the movie Blue Bicycle was made in the context of child image, together with some example films that are told from the perspectives of child heroes, who are frequently applied by Turkish directors. The cinematic narrative applied in the movie, Blue Bicycle, the children's acting experiences as real-life sections, and the plain story structure ensured that the movie was successfully transferred to the audience. As a result, the reason why the movie has succeeded, how the director has projected child image on cinematic narrative are analyzed, and the analysis of Ümit Köreken's movie was made.
\end{abstract}

Key Words: New Cinema in Turkey, Blue Bicycle, Child, Cinema, Society, Culture, Child in Cinema 


\section{Giriş}

Sinemanın diğer sanat dallarıyla olan ortak yönü, kuşkusuz içinde bulunduğu dönemin özelliklerini yansıtan öğeler bulundurmasıdır. Sanat akımı ya da sanat dalı, içerisinde bulunduğu dönemin siyasi, ekonomik, kültürel durumundan mutlaka etkilenmektedir. Toplumlar içinde bulundukları dönemleri aktif ve pasif dönüşümler içerisinde yaşamaktadırlar. Sinema da bulunduğu kültürden ve toplumdan mutlaka etkilenmiş ve dönüşümler yaşamıştır. Yönetmenler her ne kadar kendilerini dış dünyaya kapatsalar da çektikleri filmler adeta ülkelerinin birer aynasıdır. Seyirci izlediği her filmde o ülkenin sosyal ve kültürel yapısına da tanıklık eder. Sinema ticari yapısının yanı sıra aynı zamanda hem bir kültür oluşturucu hem de bir kültür aktarıcıdır. Kültür aktarıcısı olarak sinema oldukça güçlüdür ve aynı zamanda ülkelerin görsel hafızasını oluşturur (Uğur, 2017, s. 333). 2000 yılından sonra hızlıca kabuk değişimine giren Türkiye'de, değişimin izleri sinemada da görülmektedir. Bu değişim kendini bir tarafta izlenme rekorları kıran ancak eleştirmenler tarafından beğenilmeyen, güldürü ögelerinin yer aldığ1 sektör filmleri ile gösterirken, diğer tarafta da dünyaya Türk Sinemasını tanıtan, her yıl sayıları artan bağımsız filmler olarak göstermiştir. Mavi bisiklet filmi, Kültür Bakanlığı, TRT, yurt dışı fonlarıyla çekimleri tamamlanmış ve yurt içi ve yurt dışında aldığı ödüllerle Yeni Türk Sineması dünyaya tanıtılmasını sağlamıştır. Ümit Köreken bir söyleşisinde filminin kendi hayatından dair izler de taşıdığını söylemiştir: "90'larda bisiklet alma gerçekten zor bir şeydi. Bisikletim olsun diye çok çalıştım bir mavi bisikletim olsun istedim ama olmadı. Daha sonra ise bisikletin filmi oldu. Filmde 4 ana hikâye var aslında. Bu hikâyeler bizim kendi hikâyelerimiz biz bu hikâyeleri birleştirdik ve mavi bisikleti ortaya k0oyduk" (6. Seans, 2016).

Çocuk oyuncular Yeni Türk sinemasında; Genç Pehlivanlar, Sivas, Beş Vakit, Kar Korsanları, Rauf gibi filmler ile seyirciye izledikleri filmleri çocukların gözünden göstermişlerdir. Bundan önce de Türk sinemasında çocuk oyuncunun başrolde olduğu filmler vardır. Ancak genellikle bu filmlerde bulunan çocuk kahraman karakterlerin içsel dünyasını veya bunalımlarının işlendiği yapıda filmler değildirler. 'Çocukluk, Yeşilçam'da genelde mutlu sonla biten 'ailenin birliğini', 'iyiliğin gücünü’ veya 'erdemli' olmayı ön plana çıkaran anlatılarda görülür. Bu duygular, toplumsal sorunların milli reçetesini tarif eden anlatılara dönüşür. $\mathrm{Bu}$ anlatıda haliyle, çocukluğun aile ya da okulla ilgili yaşadığı krizler, sınıfsal konumunun yarattığ 1 kalıcı sorunlar veya yetişkinliğe geçiş eşiğinde yaşadığı cinsiyet problemleri görünmezdir" (Düzcan, 2017, s. 144). Fakat Yeni Türk Sineması içerisinde çocuk oyuncu kullanımı yeni bir dil arayışının da göstergesidir. Türkiye Cumhuriyeti'ne komşu olan ve yaşadığı İslami devrim doğrultusunda ciddi değişimler yaşayan İran sinemasında da anlatıyı, Abbas Kiyorastami, Majid Majidi gibi yönetmenler çocukların gözlerinden seyirciye aktarmıştır. Esasında yönetmenleri bu duruma iten sansür uygulaması olsa da bu bakış açısı son dönemdeki Türk yönetmenler tarafından herhangi bir zorunluluk olmaksızın benimsenmiştir. Türk Sinemasında Yeşilçam haricinde işlenen ve çocuklar üzerinden siyasi anlatıya yer veren fillmlerde vardır. Burada da çocuk karakterler belirli bir sıkışmışlık düzeyine indirilmiş ve çocuk kahramanlar üzerinden toplumsal sorunlar, sinemaya yansıtılmıştır. Yönetmenliğini Tunç Başaranın yaptığı Uçurtmayı Vurmasınlar (1989), Yılmaz Güney'in hapishanede çocukların durumunu işlediği Duvar (1984) filmleri bunlara örnek olarak verilebilir. Çocukların ana kahraman olarak karşımıza çıktığı Mavi Bisiklet filmi de konusu ve anlatı yapısıyla diğer filmlerden ayrılmaktadır. Adaleti çocuk gözünden sorgulayan yönetmen Ali karakteri üzerinden de kendi geçmişine de bir yolculuk yapmaktadır.

Mavi Bisiklet filmini değerli kılan bir husus da Altın Portakal Film Festivali’nde almış olduğu en iyi ulusal film ödülüdür. Bu ödül filmin Türk sinemasındaki yerini sağlamlaştırmıştır. Çünkü bu ödül Türk sinemasının önemli festivallerinden biri olan Altın Portakal Film Festivali'nin 50 yıllık geçmişinde, ulusal olarak en iyi film seçtiği ‘son' filmdir. Bağımsız filmlerin Türkiye'de yaşadığı dağıtım ve salon bulamama sorununu çözmekte önemli yeri olan Türk film festivalleri, ulusal yarışmaları kaldırarak 
henüz kurumsallaşmamış olan Türk sinemasının ilerleyişine de ket vurmaktadır. Türkiye'de organize edilen film festivallerinin, özellikle de Altın Portakal Film Festivali'nin yapıldığı ilk yıldan itibaren amacının Türk sinemasına hizmet olduğu, ulusal yarışmanın kaldırılmasıyla unutulmuştur. Mavi Bisiklet filmi Berlin Uluslararası Film Festivali’nde de en iyi film ödülü için yarışmıştır.

Mavi Bisiklet filmi seyirciye şu sorular yöneltmektedir; İnsanın yaşama amacı nedir? İyi insan olmak mı? İyi insan olmanın koşulu nedir? İyi insan olmanın koşulu, filmde çocuk bir karakter üzerinden seyirciye gösterilmiştir. Arkadaşına yapılan haksızlığa karşı çıkarak Ali iyi bir insan mı olmuştur?

Büyümüş olan insanlar bozulmuştur ve içlerinde iyi ya da erdemli bir insan olmak gayesi kalmamıştır. Onlar için önemli olan yaşamını sorunsuz bir şekilde ve yapılan haksızlıklara karşı sessiz kalarak devam ettirmektir. Yönetmen filmin nasıl oluştuğu sorusuna da şu cevabı vermiştir: Benim çocukluğumda yaşadığım bisikletle olan ilişkim 80 'de gördüğüm anti demokratik olaylar 2002'deki gazete haberleri de birleşince Mavi Bisiklet filmi ortaya çıktı (Mavi Bisiklet, 2016).

Film, Ali karakterinin hayata dair çıkmazlarını eleştirel bir yaklaşımla ele alarak, sosyolojik bir çözümleme yapmaktadır. Yönetmen yine aynı röportajındaki şu sözleriyle filmin işlenişini seyirciye hissettirmektedir: Çocukların da kendilerine ait sorunları var ve içsel olarak kendilerine göre birer çözümler buluyorlar (Mavi Bisiklet, 2016).

Mavi Bisiklet filminin incelenmesi sosyolojik, tema, sinema dili ve karşılaştırılmalı eleştiri yapılarak incelenmeye çalışılmıştır. Karşılaştırmalı eleştiri yapılırken çocuk oyuncunun sıklıkla kullanıldığı İran sinemasından da destek alınmış, İran sinemasında çocuk oyuncunun kullanım şekilleri, anlamı, durumu incelenmiş ve bunun Mavi Bisiklet filmi ile benzer yanları araştırılmıştır. Zeynep Sevinç'in dediği gibi; Türk sineması dünya sineması gibi insanı temel alan, içinde bulunduğu toplumun gerçeklerinden doğan ve yine içinde bulunduğu toplumu değiştirip dönüştürmede etkili olan bir ülke sinemasıdır. "Var olduğu günden bu yana da Türk insanın sorunlarını, çıkmazlarını ve sevinçlerini kendine özgü bir dille anlatmaya çalışmıştır. Öte yandan Türk sineması toplumu etkilediği gibi kendisi de toplumdan etkilenmektedir" (Sevinç, 2014, s. 116). Mavi Bisiklet filmi de Ali adlı karakterin içinde bulunduğu çıkmazları anlatan yönetmenin deyimiyle "Bir çocuğun adaletsizliğe karş1 çözümü nedir sorusunun cevabını aradık" (6. Seans, 2016) dediği bir filmdir. Peki, Mavi Bisiklet filminin hikâyesi nasıl oluşmuştur? Filmin içeriksel analizi ve yönetmenin seyirciye anlatmak istedikleri nelerdir? Mavi bisiklet filminde 'çocuk' öğesi nasıl kullanılmıştır?

\section{Yöntem}

Araştırmada Betimsel yöntem kullanılmıştır. Yöntem dahilinde literatür taraması yapılarak konunun anlaşılırlığı artırması hedeflenmiş ve araştırma yapılırken seçilen konu tarafsızlık ilkesi gözetilerek doğrudan aktarılmaya çalışılmıştır. Araştırmaya konu olan durum kendi koşulları içerisinde ve olduğu gibi tanımlanmaya çalışılmıştır (Karasar, 1998, s. 77). Araştırmada ayrıca içerik analizi yapılmıştır. Mavi Bisiklet filminin analizi yapılırken, genel olarak Türkiye sinemasına göz atılmış ve dünya sinemasında çocuk imgesinin fazlaca kullanıldığı İran sinemasının filmlerinden yararlanılarak filmin, çocuk temsili bağlamında analizi gerçekleştirilmiştir. 


\section{Mavi Bisiklet Filmi}

Sana dünyadaki tüm mavi bisikletleri alabilseydim çocuk

Affeder miydin yetimliği yoksulluğu

Mimi Canoğlu (Mavi Bisiklet, t.y.)

Mavi bisiklet Filmi Ümit Köreken Yönetmenliğinde 2016 yllında Türkiye ve Almanya ortaklığında çekilmiştir. Filmin Oyuncu kadrosunda Selim Kaya, Bahriye Arın, Fatih Koca Bulunmaktadır. Mavi Bisiklet filmi içerisinde barındırdığı gerçekçilik ile İran Yeni Dalga sinemasına benzemektedir. Amatör oyuncu kullanımı, doğal 1şık ve biçimsel özellikler de bu düşünceyi desteklemektedir. İran Yeni Dalga sinemasının İtalyan Yeni Gerçeklik akımından etkilendiği üzerinde durulur.

Yeni Dalga ile birlikte kamera sokağa inmiş ve sıradan insanların günlük sorunları üzerine filmler yapılmıştır. Şüphesiz bu filmlerden en önemlisi Bisiklet Hırsızlarıdır.

Öncelikle Sovyet Rusya'da ortaya çıkan gerçeklik anlayışı sonrasında kendini ikinci dünya savaşı bitiminde İtalya'da göstermiştir. Yeni Gerçekçilik olarak adlandırılan bu sinemasal dil stüdyo tipi üretim tarzına karşıdır. Amatör oyunculukla Hollywood tarzı yıldız oyuncu sistemini de reddeden İtalyan Yeni Gerçekçilik akımı doğal 1şık kullanımı, dışarıda olan ve doğal mekânlarda geçen filmler üretmiştir. Savaş sonrası ortaya çıkan işsizlik, yoksulluk, yıkım ve ahlaki çöküntüyü dekor, kostüm ve makyajı reddeden biçimsel özellikleriyle en çarpıcı biçimde ortaya koyan akım filmlerinin başta geleni De Sica'nın ‘Bisiklet Hırsızları' adlı filmidir (Uğur, 2017, s. 337).

Mavi Bisiklet filmi de amatöre yakın oyuncu kadrosu, doğal mekanların tercih edilmesi, yıldız oyuncu kavramı bulunmaması gibi özellikleri ile Yeni gerçekçi bir film olarak kabul edilebilir. Ancak yazının temel çıkış noktası filmin yeni gerçeklik ile olan bağlantısı değil çocuk imgesinin son dönemde Türk sinemasında nasıl kullanıldığ

\subsection{Filmin Tematik Yapısı}

Mavi Bisiklet filmi genel olarak Ali adlı karakterin üzerine kurulu bir filmdir. Bozulan adalet kavramını kendi içsel dünyalarında yeniden şekillendirerek, düzeltmeye çalışan iki arkadaşın dramatik öyküsü filmin konusudur. Ali karakteri kendi içsel çıkmazlarının yanında ailede yüklendiği baba rolünün filmdeki taşıyıcısı konumundadır. Öksüz oluşundan ötürü ailede baba rolünün Ali karakterinin üzerine bırakılmıştır. Ancak Ali karakteri hem baba figürünün bir parçası olarak seyirciye sunulmakta hem de hayalleri olan bir çocuk olarak seyircinin karşısına çıkarılmaktadır. Aslında bu durum Ali karakterinin tam olarak büyüyemeyiş̧inin de göstergesidir. Çocuk işçi olarak çalışmasına karşın oyun oynamak için tren raylarında saatler geçirebilir. Annesine işten aldığı parayı koşulsuz olarak teslim ederken, aldığ bahşişleri hayali olan mavi bisiklet için biriktirebilir. Bu da onun tam olarak hayatın neresinde durması gerektiğini bilmediğini, çocuk mu yoksa yetişkin mi olduğunun farkında olmadığını gösterir.

Filmdeki Ali karakteri köye sonradan gelen çocuk gibi zengin bir ailede yaşamamaktadır. Bu yüzden de çalışması gerekmektedir. Köye gelen çocuğun dedesi, Ali karakterinin babasının ölümünden sorumlu kişidir. Bu yüzden Ali ölen babasının boşluğunu doldurmak için çabalamaktadır. "Çocukluğun Yeni Türkiye Sineması'nda yetişkinliğe geçiş dönemi olarak görünür olması, toplumsal cinsiyetin 'erkek' ve 'kadın' üzerinde işlettiği rol dağılımına bakmayı zorunlu kılar. Toplumsal hayatta bu geçiş, tam anlamıyla, 'hakkıyla' yerine getirilmeden çocuklar erkekliğe ya da kadınlığa yani yetişkinliğe adım atmış sayılmazlar (Düzcan, 2017, s. 156-157).

Filmde dengelerin bozulmasının sebebi okula sonradan gelen kişidir. Burada okulun konumuna ayrı bir yer açmak gerekir. Yeni Türk Sineması'nda okulun öğretici ve yetiştirici rolü artık eskisi kadar etkili 
değildir. Hatta bu filmde okul direkt olarak haksızlığın ve adam kayırmanın temsili olarak gösterilmiştir. Başkanlıktan alınan Elif karakteri de haksızlığa uğrayan kişi konumundadır. Oysaki eski Türk filmlerinde okul, toplumu yönlendiren ve bilinçlendiren bir konumdadır. "Literatürde çocukluğun politik ve sosyal olarak inşa edildiğine ilişkin çok sayıda çalışma vardır. Ancak bu inşanın en önemli kurumlarından birisi olarak değerlendirilen okul ve ailenin, Yeni Türkiye Sineması'ndaki çocukluk kurgularında tuhaf biçimde etkisizleştiğini gözlemek mümkündür. Okul, çocukluğun inşası için önemli bir kurum olmakla beraber, onun toplumsallaşmasındaki nihai karar verici mekân değildir (Düzcan, 2017, s. 158). Nuri Bilge Ceylan'ın 'Kasaba' (1997) filmindeki okulda bu konuya iyi bir örnektir. "Bir çocuk, bütün klişeleri içinde barındıran 'aileye sevgi ve saygıyı' okumaktadır yüksek sesle. Çocuklar gerçek diye maskelenen baskın ideolojiyi sorgulamadan kabul ederler diye düşünülür ve bu hepimiz için tanıdık bir durumdur. Ceylan ilk filminin ilk on dakikasında asla çalışmayan ve çalışmayacak olan sistemlere sokar bizi, aile, milliyetçilik ve din sistemlerine" (Gezer, 2016, s. 65).

Okul artık yönetmenler gözünden sadece iyilik ve erdemli olmanın öğretildiği yer konumundan çıkarılarak, tek tip insan olma modelinin beyinlere işlenildiği yer olarak seyirciye gösterilmektedir. Mavi Bisiklet filminde de verilmek istenen anlam bu yöndedir. Okul sorgulamayan ve koşulsuz olarak itaat eden kitlelerin yetiştirildiği yer olarak gösterilmiştir. Müdür ise otoritenin en büyük temsilcisi olarak gösterilmektedir. Müdürün konuşmaları ve karakteri özellikle sert mizacı üzerinde yoğunlaşmıştır. Verilmesi amaçlanan mesaj, güçten herkesin korkması ve sindirilmesi gerektiğidir. Çocuklar koşulsuz bir şekilde iradeye boyun eğmişler ve seçimle gelen başkanlarının gitmesine razı olmuşlardır. Onun yerine otorite temsilcisi olan müdür doğrudan bir yönetici atayarak durumu kendi istediği şekilde yönlendirmiştir. Bu duruma tepki gösteren sadece Ali ve arkadaşı olmuştur. Ali ve arkadaşının yaptığı eylemler sonucunda sorunlar artmaya başlayınca, iktidarın koruyucuları olarak temsil edilen iki çocuk, bu işi yapanları Ali ve arkadaşının olması durumunda sonlarının kötü olacağı şeklinde tehdit etmiştir. Oysaki olması gereken ve doğru olan durum Ali’nin davranışıdır. Çünkü o sorgulamadan ve koşulsuz olarak itaat etmemiş ve 'onu biz seçtik oğlum' diyerek iradesine sahip çıkmaktadır. Belki de yönetmen okul ortamı içerisinde filmin oluşmasında etkili olan 80'li yılların ufak bir provasını gerçekleştirmiştir. Çünkü 1980 yılından sonra Türkiye Cumhuriyeti darbenin boyunduruğu altında eğitim sisteminde ciddi değişiklikler yaparak, sorgulayan öğrenci akışını bozmuş yerine ezberci ve itaatkâr bir nesil yetiştirme gayretine girmiştir. Filmdeki bu durumun sadece bir çıkarımdan ibaret olduğu unutulmamalıdır. Bu çıkarıma temel olarak gösterilebilecek olan bizzat yönetmenin dile getirdiği şu cümle olabilir: "Benim çocukluğumda yaşadığım bisikletle olan ilişkim 80'de gördüğüm anti demokratik olaylar 2002'deki gazete haberleri de birleşince mavi bisiklet filmi ortaya çıktı" (Mavi Bisiklet, 2016).

Çocuklar çözümleri her zaman kendisi bulur tezine bir gönderme olarak, film çocukların gözünden sosyolojik çıkarımlar yapması ve ülkenin durumunu anlatması bakımından İran filmlerine benzediği aşikârdır. Filmin, içerik ve çocuğun sorunlara çözüm buluşu ve içinde yaşadıkları adalet ve doğru davranış kavramları gibi öğeler düşünüldüğünde Abbas Kiroyostami’nin Köker üçlemesi filmi olan Arkadaşımın Evi Nerede? (1987) filmine de benzemektedir. Orada da çocuğun gözünden dönemin yapısı seyirciye gösterilmiştir. Arkadaşımın Evi Nerede? (1987) filminde otoritenin göstergesi olarak yine öğretmen simgesi kullanılmıştır. Öğretmen için öğrencilerin yaptıkları ödevler önemsizdir onun için önemli olan disipline ve kendi koyduğu kurallara uyulmasıdır.

Hayat tehditlerle doludur. Çocuklar, iktidar sahibi, otorite sahibi ve bu otoritesini kendince haklı nedenlerle anlatan bir öğretmenin egemenliği altında ezilirler. Hayatta, kendince haklı sebepleri olan ve bu sebepleri anlatmaktan çekinmeyen büyükler vardır hep. Tabii ki ailelerinin verdiği işler vardır çocukların başında, çünkü ailevi meseleler ve zorunluluklar hep olacaktır hayatta. Bütün bu baskıların, otoritenin ve anlamsız işlerin altında ezilir çocuklar. Ama Ahmed A. Poor 
bütün bunları hayatın içinden bir şey gibi kabul eder. Adeta normal şeylerdir bunlar Onun için. O bütün bunları hayatın içinden olarak alır ve öyle devam eder (Gezer, 2016, s. 67).

Okul müdürü dinlemeye kapalı ve otoriter olarak öğrencilerle özne-nesne ilişkisi içerisindedir. $\mathrm{Bu}$ yüzden de öğrencilerin hayatlarına dokunamamaktadır. Oysa Anadolu toplumundaki öğretmen algısı bunun tam tersi yönündedir. Filmdeki Öğretmen karakteri Ali'nin gözünde, babasının ölümünün sorumlularını söylemelerine karşın onlara inanmayan adalet kurumları kadar kötüdür. Öğretmen çevresine karşı oldukça kapalı bir konumda dururken, Ali karakteri öğretmeninin tam zıttı bir karakterdedir. Kendine ait olmayan bir sorun yüzünden çocukluk hayali olan mavi bisikletten bile vazgeçerek, çevresinde oluşan adaletsizliğe karşı aktif olarak tepki vermiştir. Filmi çocukların bireyselliğini tanımayan, onları yalnızca eğitilmesi gereken varlıklar olarak gören klasik eğitim sisteminin bir eleştirisi olarak okuyabiliriz. Mavi Bisiklet filmi otoriteye boyun eğmeyen, sorgulamaktan ve inandığı doğrulardan vazgeçmeyerek yeni yollar arayan zihinleri de ifade etmektedir.

\section{2. Çocuk İmgesinin Mavi Bisiklet Filmindeki Yeri}

Yazının ikinci bölümünde Majid Majidi’nin 'Cennetin Çocukları' (1997) filmindeki çocuk karakterler üzerinde Mavi Bisiklet filmi ile karşılaştırmalar yapılacaktır. Aynı zamanda Yeni Türk Sineması'ndaki çocuk karakterlerin nasıl bir işlevde olduğuna kısaca göz atılacaktır.

Majid Majidi sinemaya 90'lı yıllarda rejim baskılarının yumuşadığı eleştirel seslerin yükseldiği, sinemacıların kendi öykülerini kısmen de olsa anlatabildiği ve 'sosyal sinema' olarak adlandırılan önceye göre daha özgürlükçü bir dönemde başlamıştır. Bu yıllar kadınların erkek kıyafetleriyle afişlerde görülebildiği ve filmlerde rol alabildikleri, tabuların yıkılmaya başladığı bir atmosfere sahiptir ve hikâyelerde çocuk bakış açısı egemendir (Uğur, 2017, s. 338)

Oysaki Mavi Bisiklet filmi yönetmeni Türkiye Cumhuriyeti'nden kadın oyuncu kullanımı ya da başka sorunlar yüzünden değil, olayları bilinçli olarak çocuk bakış acısından göstermeyi tercih etmiştir. Bir yönetmenin belki de zorunluluk olarak gördüğü durum Ümit Köreken için anlatı dilinin temelini oluşturmaktadır.

Türk sinemasında genellikle edilgen ve yardımcı karakterler üzerinden anlatılan çocuklar bu filmde başkarakter konumunda ve tüm sorunların odak noktasında bulunmaktadır. Yeni dönem Türk sinemasında çocuk oyuncular sıklıkla başkarakter konumunda tercih edilmiştir. Eski filmlerde daha çok bir imgenin baş temsilcisi veya kahraman öğelerin anlatıldığı filmlerde yer verilen 'çocuk' karakterlere Yeni Türk Sineması'nda içsel sorunlarını, dertlerini, yaşadıkları bunalımlarıyla yer verilmiştir. Sezercik Aslan Parçası filmindeki karakterle Ümit Köreke'nin çocuk karakterinin tek benzer oldukları nokta 'çocuk' olmalarıdır. Bunun dışında Semih Kaplanoğlu'nun Bal (2010) filmindeki Yusuf karakteri, Sivas (2014) filmindeki Aslan karakteri, Hayat Var (2008) filmindeki Hayat karakteri de, tıpk1 Mavi Bisiklet'teki Ali karakteri gibi filmin ana kahramanlarıdır. Hepsinin ortak noktası çocuk olmalarının yanı sıra içsel bunalımları ve çıkmazları olmasıdır. Aslan karakteri büyümeye ve erkek olma mücadelesi içerisinde, sevdiği kıza ve köylüye kendini ispat etme peşindedir. Yusuf karakteri ise okumayı öğrenmesine karşın içine kapanıklığından dolayı hedeflediği kırmızı kurdeleye sahip olamaya çalışmaktadır. Hayat, İstanbul'un griliğinde bir adada hapis hayatı yaşamakta ve buradan İstanbullu olmayan birisi tarafından kurtulmanın peşindedir. Ali karakteri de hayali olan mavi bisikleti satın alamasa da kendi yaptığı mavi bisiklet ile filmin sonunda kendi özgürlüğüne doğru pedal çevirmektedir. "Yaşamaya devam edebilme ya da edememe meselesi sadece mutlu sonla bitme ya da bitmeme meselesi değildir. Aslında derine inildikçe meselenin, yukarıda da bahsedilen şekliyle, filmlerde kurulan hayat tasarımıyla ilgili olduğu anlaşılır" (Gezer, 2016, s. 62). Bu filmlerde unutulmaması gereken konu filmin sonrasında da hayatın bu çocuklar için devam ettiğidir. 
Yazının temelini oluşturan çocuk imgesine parantez açarak filmdeki anne figüründen bahsedilmesi de gereklidir. Filmdeki anne figürü geleneksel olarak suskun, dış dünyaya kapalı ve kendi iç dünyasında yaşamaktadır. Dul bir anne olması da filmde, Ali karakterinin yaşadığı çıkmazların sürekli olarak büyümesine neden olmaktadır. Türkiye sinemasındaki suskun kadın imgesini bu filmde de görmekteyiz. Filmin, kadının kocasını öldürenleri bulunduğu sahnede bile sevincini kısık sesle yaşadığı sahne seyircide sessizlik sorgusu yaratmaktadır. Burada kadının ikinci konumunda olduğu seyirciye gösterilmeye çalışılmış olabilir.

Orta Doğu kültüründe kadının başlıca vazifesi, evde oturmak, neslin devamını sağlamaktır. Evden dışarı tek başına çıkmaya cüret edecek olur ise toplumca iffetsiz olarak suçlanmaktadır. Ayrıca yine bu kültürde iyi kadınlardan beklenen hareketler sorgusuz sualsiz itaat etmektir. Çünkü erkekler bu toplumlarda erkekler kadınlardan daha akıllıdır. İyi kadın soru sormadan erkek büyükleri için her şeyi feda etmeye hazır ve erkekleri emirlerine amadedirler. Verilen emirleri harfiyen yerine getirmekle sorumludurlar (Tapper, 2007, s. 272).

Tapper'in söylediği bu sözün tüm Ortadoğu ülkelerinde geçerli olup olmadığı tartışma konusudur. Ancak Türk sinemasında birkaç uç örnek dışında kadın temsili genellikle Tapper'in bahsettiği gibi sinemaya aktarılmıştır. Ancak bu durumun tersi olarak işlenildiği filmlerde vardır. Örneğin Yavuz Turgul'un Fahriye abla filminde işlenilen kadın karakter evden çıkarak çalışma hayatına atılmış ve Türk sinemasında tabir edilen 'kötü yola' düşmeden kendi hayatını sürdürmüştür. Toplumun ona biçtiği anne rolünden oldukça uzak bir biçimde işlenen Fahriye abla filmindeki kadın karakter, aslında Tapper'in söylediğinin her zaman doğru olmadığını da seyirciye göstermektedir.

Mavi Bisiklet filmindeki kadın karakter bu olguların dışındadır. Çünkü kendi adaletini aramak için tek başına bir yola çıkmıştır. Davalı olduğu kişinin tehditlerine boyun eğmemiş hatta ataerkil yapıdaki 'karşı çıkılmaması gereken erkeğe' karşı çıkarak geciken adaletin yerini bulmasını sağlamıştır. 'Ali annene söyle bu davadan vazgeçsin. Bunun sonunda zararlı çıkan siz olursunuz’ repliği de aslında toplumun erkek egemen yapısına yapılmış bir vurgudur. Anne tüm bu zorlama ve baskılara rağmen gelen adaletle kısık sesle de olsa sevincini yaşaması belki de filmin en önemli sahnelerindendir. Çünkü anne de Ali gibi adaleti sağlamak için kendi toplumsal kurallarını çiğnemiş, sonunda da oğlu gibi o da özgürlüğe karşı bastırılmış da olsa bir sevinç yaşamıştır.

\section{3. Çocuk Karakterlerin Filme İşlenişi}

Mavi Bisiklet filmi gibi çocuk karakterli bir film olan 'Cennetin Çocukları' (1999) filminin öyküsüne dönülecek olur ise; film kız kardeşinin ayakkabılarını kaybeden fakir bir ailenin erkek çocuğu ile kardeşinin tek bir ayakkabıyı değişerek kullanmalarını masalsı bir şekilde anlatmaktadır. Filmde, okula giden iki kardeş ayakkabılarını dönüşümlü giymek zorunda kalırlar. Zehra, dersten erken çıkar. Ali ile bir sokak arasında ayakkabılarını değiş̧irirler. Ali koşarak gittiği halde hep derse geç kalır ve azar işitir. Ali, üçüncülük ödülü spor ayakkabı olan bir yarışmaya girmeye karar verir. Amacı üçüncü olup kazandığı ödülü Zehra'ya vermektir. Ayarlamaya çalışsa da birinci olur ama ayakkabıyı alamadığı için çok üzgündür. Aslında iki filmin de ortak yapısı öykülemede kullandıkları insan doğasıdır.

Klasik anlatı filmlerinin aksine iki filmde de yıldız oyuncu kullanılmamış ve dış gerçeklik yalın bir dille anlatılmıştır. Diğer bir ortak nokta ise filmlerin senaryo yazarlarının da yönetmenler oluşudur. "Majidi filmlerinde en küçük ayrıntıları hiç kaçırmadan dramatik bir şekilde işlemektedir. Ahlakı ve düşündüğü bütün duyguları zekice bir kurguyla beyaz perdeye aktarmaktadır. Filmlerinde saklı kalmış duyguları, gizemi ve İran'ın bütün mitlerini kusursuzca düşündürmeye dayalı bir dille insan zihnine göndermede bulunmaktadır" (Yaghmoorala, 2013, s. 53). Mavi Bisiklet filminde de insanı düşünmeye sevk eden durum, çocukların bir soruna karşı büyüklerden daha fazla duyarlı olmasıdır. Ana karakter yapılan haksızlığa karşı bir direniş içerisine geçmiştir. Türkiye konum itibari ile iki kıtanın kesişim noktasında 
bulunsa da ahlaki kurallar olarak doğu kültürünün özelliklerini barındırmaktadır. "Doğu düşüncesi özne/nesne ayrımına yer vermez; kendini dünyaya eklemlenmiş bütünün bir parçası olarak görür. Batı kültürlerinde farkl1lık ve bireysellik vurgulanırken Doğu kültüründe ise topluma uyum ve toplumsal benzerlikler ön plana çıkartılır" (Sözen, 2012, s. 219). Burada genel topluma uyması beklenen Ali karakteri bunun tam zıttı bir hareketle arkadaşı ile birlikte doğru bildikleri yolda ilerlemişlerdir. Aslında film buradaki çatışma ögesiyle Cennetin Çocukları'ndan ayrılmaktadır.

Cennetin Çocukları'ndaki karakterlerin sorunları kendilerine aittir ve bu sorunu çözmek için bir çözüm arayışına girmişlerdir. Ancak Ümit Köreken'in 'Mavi Bisiklet' filmindeki Ali, kendisi için istediği mavi bisikleti, yani hayallerini bırakarak başkalarına yapılan haksızlığa karşı bir mücadele içine girmiştir. Filmin etkisini artıran çocuk oyuncular, birer film yıldızı olmaktan ziyade orada gerçekten yaşayan birer insan konumundadırlar. Tapper'in şu sözü de tam olarak bu filme uygundur; 'Ancak çocuk olarak kendimiz olabiliriz'.

'Sana tüm mavi bisikletleri alabilseydim çocuk, affeder miydin yetimliği yoksulluğu', Mimi Canoğlu'na ait bu şiir aslında hem Mavi Bisiklet filmini hem de Cennetin Çocukları filmini en iyi anlatan dizelerdir. Yönetmenin de söylediği gibi herkesin çocukken hayalini kurduğu bir mavi bisiklet vardır. Ali, yoksulluğa rağmen biriktirdiği parayla hayalini gerçekleştirmenin peşindedir fakat karşısına vicdani olarak daha büyük bir problem çıktığı için hayallerini ertelemek zorunda kalmıştır. Ali karakteri yoksul ve fakirdir ancak bu yoksulluk ve fakirlik kesinlikle utanılacak bir fakirlik değildir, aksine Majid Majidi'nin dediği gibi onur, izzet, ihtişam taşımaktadır. Ümit Köreken'in Mavi Bisiklet filminde İran Sinemasının bir başka özelliği olan ailenin tüm sorumluluklarını üstlenen çocuk imgesi de karşımıza çıkmaktadır. Çocuk burada aslında Türkiye'nin içerisinde bulunduğu yaşam şartlarını ve kültürünü, bulunduğu şehre bağlı olarak seyirciye göstermektedir. Tapper'in şu düşüncesi Mavi Bisiklet için de geçerli olabilir; "Çocukların sunduğu en kıymetli tecrübe olarak oyunculuk dışı üslupları sayılabilir. Kendilerine has bir ustalığa sahip olup, oynadıkları karakterlerde kendi hayatlarının bir eşini canlandırmışlardır”' (Tapper, 2007, s. 228).

Yönetmen hem toplumsal sorunları hem de karakterin içinde bulunduğu çıkmazları, gündelik yaşamın görüntüleriyle minimalist bir biçimde seyirciye göstermektedir. Yönetmen tüm bu sorunları seyirciye aktarırken geçmişinde bulunan çocuk tiyatrosu yazarlığ ve çocuklarla yaptığı çalışmanın yanında, büyüyen insanların bozulan iyi niyetlerine ve haksızlıkları görmezden gelmelerine karşı, hala bozulmamış saf iyinin temsilcisi olan çocukları tercih etmesi de filmin anlatı yapısını güçlendirmiştir.

Saflık ve temizliğin göstergesi olarak Cennetin Çocukları'ndaki karakterlerle de Mavi Bisiklet filminde karakterler benzemektedir. İki filmde de çocuk oyuncuların taşıdıkları yük yaşlarından oldukça büyüktür. "Majidi'nin filmlerinde çocuklar, omuzlarındaki boylarından büyük yükleri boylarından büyük yürekleriyle zor ama yine de çocukluklarını unutmadan taşırlar. Zamanından önce büyümek zorunda kalmanın sancısını yetişkinlere nispet olgunluklarıyla dindirmeye çalışılar" (Yaghmoorala, 2013, s. 111). Mavi bisiklet filminin başarısı karakterlerin içinde bulundukları durumu, hayatın gerçekliğini bir sömürü öğesi yapmadan kendi hikâyeleri gibi seyirciye göstermesinden kaynaklanmaktadır.

"Bilgi akışını getiren ve dramatize eden, dolayısıyla da seyircileri içerisindeki bağlanma tarzlarını depolitize eden film yıldızlarının aksine, çocuklar gerçek dünyayı temsil etmektedir” (Tapper, 2007, s. 297). İnsan ister doğu felsefesinde olsun ister batı felsefesinde olsun yaptığı seçimlerden kendisi sorumludur. "Bireyin önceden çizilmiş/belirlenmiş bir özü veya kaderi yoktur; birey kendi seçimleriyle kendisini ve hayatını var edecektir" (Sözen, 2012, s. 230). Burada da Ali karakteri yaptığ seçimle kendine göre doğru olanın yükünü taşımaktadır. Ancak bu seçiminden dolayı suçlanması ya da ceza görmesi de kendi seçtiği yolun sonucudur. "Seçenekler arasında kalındığında kişinin verdiği karar ve 
seçtikleri -dışarıdan bakıldığında- onu doğru veya yanlış, haklı ya da haksız konumlarından birine getirir. Tercih edilen seçimde 'bu ne kadar doğru' sorusunun net bir yanıtı olamaz” (Sözen, 2012, s. 231).

$\mathrm{Bu}$ filmde de Ali karakterinin yapılan haksızlıklara karşı tavrı ne kadar doğru ya da yanlış diye tartışılamaz. Çünkü ortada yanlış bir durum vardır ve Ali kendi doğrularıyla bu duruma müdahale ederek çözmeye çalışmıştır. Çözüm aşamasında sistemi bozacak ve tedirgin edecek birçok ögeyi de farkında olmadan kullanmıştır. Ali tüm bunların sonucunda gazetelere çıkmış, haber olmuştur. Oysaki onun gazeteye ya da habere ihtiyacı yoktur. Ali'nin tek amacı hayali olan mavi bisiklete ulaşmaktır. Ancak bu yolda ilerlerken gördüğü haksız durum karşısında olaylara müdahale ederek, ulusal çapta bir örgütlenmeye ve gazetelerde, yaptığı olayın haber olmasına sebep olmuştur. Adalet için verilen mücadele ortak ve evrensel bir sorun olduğu için de, kaçınılmaz olarak seyirciyi kendisini sorgulamaya itmektedir. Çünkü kullanılan yöntemler tartışılmaya açıktır. Ancak yöntemleri kullananların birer çocuk olduğu düşünüldügünnde yaptıkları şeyin doğru ya da yanlış oluşu ortadan kalmış ve dik duruşlarından dolayı medyada haber olmuşlardır. Ali filmin sonunda yaşanılan tüm sorunlara rağmen kendi elleriyle hayalindeki mavi bisiklete kavuşarak seyirciyi de hayallerine ortak etmiştir.

\section{Sonuç}

Ümit Köreken'in Mavi Bisiklet filmi içinde bulunduğu toplumsal, siyasal ve kültürel yapın etkilenmiştir. Türkiye özellikle 2000 yılından sonra hızlıca bir değişim içerisine girmiştir. Bu değişim sonucunda kuşkusuz sanat dalları da etkilenmiştir. 2010 sonrası Türkiye Sineması bu doğrultuda, Tolga Karaçelik, Mustafa Kara, Ümit Köreken gibi henüz ilk filmlerinde başarıya ulaşmış ve evrensel bir dil kullanan sinemacılar ortaya çıkarmıştır. Altın Portakal Film festivali'nden ödülle dönen Mavi Bisiklet filmi de yönetmenin kendi iç dünyasını, içinde yaşadığı toplumu ve kültürü sade bir dille seyirciye göstermiştir. Film, dış gerçekliği olduğu gibi aktaran, yıldız oyuncu kullanımı bulunmayan ve güçlü öykü yapısıyla seyirciye çocuk gözünden bir sorun ya da adaletsizlik karşısında nasıl davranılması gerektiğini anlatmaktadır. Filmin içerisinde çok az müzik kullanılarak dış gerçek bozulmadan gösterilmeye çalışılmıştır. Filmde, yapılan haksızlığa karşı savaş açanların ötekileştirildiği veya cezalandırıldığı düzen üzerine kurulu bir anlatım vardır. Özellikle doğu kültürlerinde topluma uyum önemli bir kavramdır. Film çocuklar üzerinde toplumsal olarak yanlış olan bir duruma karşı savaşılması gerektiğini göstermeye çalışmıştır. Filmde kullanılan çocuk oyuncu ise eski Türk filmlerinden farklı olarak çocuk karakterleri etkin bir rolde göstermiştir. Bu bağlamda İran filmlerinde kullanılan çocuk karakterlere benzese de İran sinemasından anlatım olarak farkl1lıklar göstermektedir. Sansür yüzünden çocuk oyuncuya yönelen İran sinemasının aksine Mavi Bisiklet filminde, çocuk karakterler ile filmin etkisi artırılması hedeflenmiş ve filmin ana fikri olan haksızlığa başkaldırı öğesini çocuklar üzerinden seyirciye göstermiştir. Film tüm çıkmazların nedenini öğretmenin ağızından çıkan Ailesi şehre gidiyor o yüzden başkanlığı aldım sözleriyle çözüme kavuşmuştur. Ali ve arkadaşının çocuk olarak, haksız gördükleri olaya karşı bir baş kaldırı hikâyesini anlatan

Mavi Bisiklet filminin güçsüzleşen Türkiye sinemasında istisna sayılan işlerden olduğu aşikârdır. 2016 yılında Altın Portakal Film Festivali'nden en iyi yönetmen, en iyi senaryo, en iyi film ödülleri almış olması da filmin değerini göstermektedir. Bunda şüphesiz evrensel bir konuyu çocuklar üzerinden işleyişinin payı büyüktür. Altın Portakal Film Festivali’nin 54 yıllık tarihinde Gurbet Kuşları'yla Türk Sinemasına verilen destek, Mavi Bisiklet filmi ile son bulmuştur. Bu da bağımsız yapımların ayakta kalmasına ket vuran bir duruma dönüşmüştür. Ümit Köreken gibi ilk filmlerinde başarıya ulaşmış yönetmenlerin desteklenmesi için Türkiye'de Türk filmlerine verilen desteklerin arttırılması önemlidir. Bu doğrultuda Yeni Türk Sinemasının önemli bir filmi olan Mavi Bisiklet filmini karşılaştırılmalı ve içeriksel olarak analizi yapılarak neden iyi bir film olduğu araştırılmıştır. Mavi Bisiklet filmi evrensel 
değerlere ulaşan sinema diliyle, çocuk masumiyeti üzerinden sinema anlatısı gerçekleştirmiştir. Ümit Köreken filminde daha önce çocuklarla yaptı̆̆ çalışmaların sonucunda çocuk dünyasını ve çocukların birbirleriyle olan ilişkilerini, aile ile durumlarını ve içsel dünyalarını başarılı bir şekilde filme aktarmıştır. Bunun sonucunda da anlatım dilinde zorluk çekmeyen ve seyirciye ifade edeceklerini doğru bir şekilde aktaran bir film ortaya çıkmıştır. Bağımsız film yapımı yaşadığı tüm sorunlara rağmen Türkiye'de var olmaya devam etmekte ve Mavi Bisiklet filmi gibi filmler sayesinde de Türkiye sinemasını yurt dışına taşımayı sürdürmektedir. Bunun yanında değişen Türk sinemasında çocuk karakterlerin kullanımının da değiştiği görülmektedir. Edilgen bir boyutta ana karakterleri destekleyici durumdan çıkarılan çocuk oyuncular, İran sinemasının aksine sansürü delmek için değil, Yeni Türk sinemasında baş karakterler olarak seyircinin karşısına çıkmaktadır. Çocuk kahramanların Yeşilçam dönemindeki kullanımın aksine Ümit Köreken sinemasında içsel bunalımların işlendiği, toplumsal çatışmaların çocuk gözünden seyirciye aktarıldığı görülmektedir. Sonuç olarak Türk Sineması çocukların içsel dünyalarının anlatıldığı, politik söylemlerin işlenildiği, Sivas, Beş Vakit, Bal, Genç Pehlivanlar, Mavi Bisiklet gibi filmler ile kendini dünya sinemasına anlatmaya devam etmektedir.

\section{Kaynakça}

6. Seans. (2016, 19 Aralık). Ümit Köreken Mavi Bisiklet filmi söyleşisi [Video]. Erişim Adresi: https://www.youtube.com/watch?v=KM4lqiL9d3A

Düzcan, B. (2017). Yeni Türkiye sinemasında yetişkinliğe geçiş: Sivas ve hayat var filmlerinde cinsiyet, güç ve oyun. Akdeniz İletişim Dergisi, 144-158.

Gezer, S. (2016). Varlığın içkinliğinden türeyen hayat fikri: Abbas Kiarostami, Nuri Bilge Ceylan, Zeki Demirkubuz sinemalarına bakış. Sine Filozofi, 1(1), 62-67.

Karasar, N. (1998). Bilimsel araştırma yöntemi. Ankara: Nobel Yayınları.

Mavi Bisiklet Şiiri. (t.y.). Erişim Adresi: https://www.edebiyatdefteri.com/siir/881492/mavibisiklet.html

Mavi Bisiklet/Blue Bicycle (2016, 7 Nisan). İstanbul Kültür Sanat Vakfi Ümit Köreken Mavi Bisiklet filmi söyleşisi [Video]. Erişim Adresi: https://www.youtube.com/watch?v=8eJWYkCgnF4

Sevinç, Z. (2014). 2000 sonrası yeni Türk sineması üzerine yapısal bir inceleme. Dumlupınar Üniversitesi Sosyal Bilimler Dergisi, 40, 97-118.

Sözen, M. (2012). İran yeni dalga sinemasında varoluşsal temalar ve yönelimler. Selçuk Illetişim Dergisi, 7 (3), 218-233.

Tapper, R. (2007). Yeni İran sinemast: siyaset, temsil ve kimlik (K. Sarıözen, Çev.) İstanbul: Kap1 Yayınları.

Uğur, U. (2017). İran yeni dalga sineması ve Majid Majidi'nin "Cennetin Çocukları" filmi. Ordu Üniversitesi Sosyal Bilimler Araştırmaları Dergisi, 7 (2), 333-342.

Yaghmoorala, M. V. (2013). Majid Majidi filmlerinde sosyal ve kültürel anlatı yapısı (Yüksek Lisans Tezi). YÖK Tez veri tabanından erişildi (Tez no: 337422). 